\title{
The Drive towards Application of Pragmatic Perspective in Educational Research: Opportunities and Challenges
}

\author{
John F Kalolo (PhD) \\ Mkwawa University College of Education \\ Faculty of Education, Psychology and Curriculum Studies Unit \\ Iringa, Tanzania \\ E-mail: mwakalolo@yahoo.ca
}

Received: Dec. 2, 2014 Accepted: Feb. 10, 2015 Published: February 10, 2015

doi:10.5296/jse.v5i1.7145 URL: http://dx.doi.org/10.5296/jse.v5i1.7145

\begin{abstract}
With increased attention to the importance of educational research theories and practice in recent years, a concern has arisen about the methodological and theoretical conflicts in research. Far seen is a proliferation of other types of research theories (such as positivist, constructivist, and critical theory) and other methodologies (such as mixed methods), all of which involve research disagreements. This situation not only reduces the efficiency of each methodology and theory in the development of knowledge, but also presents a challenge in selecting the most appropriate methodology for a particular research. As such, the need has therefore been to have a research paradigm that can accommodate a variety of research methodologies and use them to achieve a deeper level of understanding about a particular phenomenon. This paper proposes an intermediary perspective (that is, pragmatism) for integrating different research methodologies even when their strengths and emphases differ substantially. The increasing demand for a pragmatic perspective in educational research is based on the idea that: Pragmatism is better equipped than any other approach because of its power of complementarity whereby the weakness of one methodology is complemented by the strengths of the other methodology; pragmatism is a foundation of mixed methods; it can be easily adopted to yield better research outcomes; and it is based on the need to enrich the research data produced. Although a number of challenges to using this perspective remain, the potential insights generated by its strengths in educational research are substantial.
\end{abstract}

Keywords: Pragmatic approaches, Pragmatic perspectives, Educational research 


\section{Introduction}

A number of new research frameworks in education have sprung up in recent years each one having a negative view of the others. Different types of models and frameworks have been employed in studying and solving educational issues (Hammersley, 2002; Singh, 2007). Though one can regard the situation as advancement in educational research, the reality is that such developments have limited the richness of the data produced due to established boundaries in knowledge development (Johnson \& Onwuegbuzie, 2004). The recent methodological tug of war among several research methodologies, such as positivist and constructivist, has echoed the response that some methodologies work reasonably well to solve problems in education but they are not effective enough when used on their own (Johnson \& Onwuegbuzie, 2004; Rallis \& Rossman, 2003). This idea of one-dimensional constructs in educational research presents a limited measure that fails to meet the current requirements of the highly complex educational systems. This limitation has also brought a need to have multidimensional approaches to maximise the inquiry outcomes in education (Maxcy, 2003; Morgan, 2007).

Many theories, models, and paradigms in education, however, are inordinately complex, consisting of a huge number of steps or component parts in an effort to be comprehensive, but having many limitations, and often containing substantial jargon and terminologies, thus making them challenging to implement and failing to produce dependable research data that can authentically solve multi-sourced educational problems (Johnson \& Onwuegbuzie, 2004). This paper presents pragmatism as a new perspective in educational research that would help in bringing the gap between educational theories and practice, and act as an intermediary perspective among different contrasting perspectives.

The paper seeks to critically discuss pragmatism as a general methodological approach to educational research. In the first place the paper looks at the conceptual gaps in research methodology. This is followed by a review of its general conceptual meaning, foundation, and principles of pragmatism. The final section of the paper presents a conclusion about pragmatism as an approach to education research formulated on the basis of the reviewed material.

As used in this paper, a pragmatic perspective is regarded as an intervention approach that is likely to guide what should be done to produce successful educational research outcomes and a framework that would guide the types of questions that should be asked to assess how successful educational interventions have been or are likely to be. The adoption of this perspective is based on the idea that in spite of a growing interest in epistemological, phraseological and axiological issues, in research, there is still a lack of critical reflection in the selection and use of methodologies in educational research. The application of pragmatism in educational research is also based on the attempt to link educational theories to practice describe and solve educational challenges in their contextual setting, and bring the relevance and functionality of the education to the public. Of course, there are many well-established theories in educational research (such as positivism, constructivism, critical theories, and so on), but it should not be understood that pragmatic approaches are the best; 
rather they should be understood as the ones that show promising opportunities to address different research methodological crises. Therefore, the focus of this paper is to reflect philosophically on how the educational research outcomes can be made useful, relevant, and functional in solving the contextual educational problems through the implementation of pragmatic lenses. The next sub-section discusses the existing research methodological challenges.

\section{The Evidences of Methodological Predicaments in Educational Research}

The recent developments in educational research show that there are some notable methodological problems (Badley, 2003; Glasgow \& Riley, 2013; Hope\& Waterman, 2003; Mukusha, 2011). For the purpose of this paper, here follows a few methodological examples of problems that have arisen in educational research and how they affect educational practice. Some of these problems include: indecent research expectations; infallible research outcomes; questionable dualism; debatable primacy of positivism; and false certainty. The details of these problems are presented in the sub-sections that follow.

\subsection{Indecent Research Expectations from Educational Research Outcomes}

Concern has arisen on the way the research beneficiaries (the government and other funding bodies) are forcing educational researchers to shift to quick evidence-based research (quantitative) which is believed to have solutions to all educational problems. For example, in most countries today for one to get research funding, it is required that the research should be large scale, multidisciplinary, and quantitative in nature to serve evidence-based practice. Hammersely (2002) calls this situation an inappropriate engineering model to education research that raises false expectations about educational research outcomes. Hammersely is concerned about its fallibility, temporary validity, and provisional authority that this kind of research has in producing the cumulative body of knowledge that would benefit educational practice. Hammersely's view is based on the idea that traditional research (quantitative or qualitative) can only:

- Represent a fraction of ways of how to cope with some educational problems but not all.

- Only offer a fraction of modest practical contribution but not all.

Similar to Hammersely's (2002) view, Rorty (1999a) admits that though positivistic approaches may have some value in educational research and practice, they are not sufficient in providing a single comprehensive perspective that can explain and provide solutions to all educational problems.

\subsection{Problematic Dualism of the Research Methodologies}

A problematic account has been identified on the false dualism between positivist and constructivists on the way they view research outcomes, the researched, and the reality. Pring (2002) calls this kind of epistemological and ontological apartheid as a reason for contributing to the divide of researchers and that this situation limits the usefulness of the research outcomes produced and affects educational practice. Rorty (2000) argues that although the traditional positivistic approaches in research are glorious and successful for the 
purpose for which they were developed; they are not enough to provide "redemptive truth" (p.12).

Rorty (2000) and Pierce(1935)argued for the recognition of methodological differences that exist between the world views because it is clear that while some inquiries provide propositions, others provide narratives. But for effective research outcomes both narratives and proposition are important. It is at this point where Rorty agrees with Pring's (2002) view that altogether rejects positivism, and argues the need for researchers to be eclectic in their search for truth because the description of reality, whether based on positivism or constructivism, is partial and almost irredeemably fuzzy and insufficient on their own. Pring calls for a more democratic approach similar to pragmatism which is likely to produce tentative knowledge claims open to further refinement and critique, and considers critical consensus (p.115). In a similar way, Rorty (1999b) sees a need to shift from celebrating the frameworks and world views that only end up describing "how things really are" to the frameworks that describe how things might best be addressed in order to meet the human needs (p.14).

\subsection{Notable Primacy of Positivism}

Educational research is also challenged by the dominance of positivistic, scientific, and outcome oriented performative research approaches. Brew (2001) describes this factor as a tragedy in research that contributes to swaying the researchers to unhelpful and premature research outcomes that are not really helpful in the improvement of educational practice and then trap the researchers within a methodological noose of patriotism and objectivism. Similar to Rorty's (1991) views, Brew considers the necessity of the following:

- A shift from a closed positivistic system of research to a more open and pluralistic approach of inquiry.

- A shift from approaches that make us believe that this is how things are towards those that will help us critically reflect on the happenings and see how to address them.

- Shifting from dogmatic approaches towards those that can lead to a critical conversation and consensus.

- Shifting towards approaches that welcome multiple views on the complexities in education.

Generally, this is to say that the research process should not lead to a golden city of complete truth but rather should lead to the beginning of new debate regarding the newly established knowledge. This means shifting towards embracing research perspectives such as pragmatism which is likely to widen the criteria for judging truth and thus is able to increase the usefulness of research outcomes in solving public educational problems.

\subsection{Infallible Research Outcomes}

Most research outcomes are faced with a problem of rigidity and inflexibility to being criticized. Pragmatically, this challenge is called infallibilism in which the research outcomes are presented as recipes of knowledge with no chance for new evidence that would contradict some previously held position or belief (Kompridis, 2006). This challenge limits the 
possibility of the research outcomes produced to be revised or withdrawn in light of new evidence, new arguments, and new experiences.

Kompridis (2006) argues that the dominant traditional research paradigms have restricted the consciousness of and the degree to which research interpretations, valuations, practices, and traditions can be created temporally indexed and subject to (possibly arbitrary) historical flux and change. This neglect of change in the positivist methodologies has also limited the predictions of a possibility that one would anticipate in the future assuming that certain conditions would have changed. The dominance of foundationalism methodological principles in research has also led to the following consequences:

- Misusing research evidence whereby the evidence from other lines of inquiry containing the conflicting evidence have been misevaluated, overlooked, and disvalued.

- Representational limitations of research evidence whereby certain language, thoughts, and styles have been regarded as the correct ones in describing the reality or the research outcomes. As such, misleading and clumsily constructed thoughts have dominated the research arena, the situation which limits its applicability and their usefulness to solve the challenges at hand.

- Factual limitations whereby several mistakes of facts have been made due to some researchers holding biases and prejudice that impede their ability to articulate a concept with a broader view.

Fallibilism does not imply abandonment of the previous research methodologies but an acknowledgement of the strengths and weaknesses of each and creating a chance for improving them through integration of ideas from contrasting methodologies.

\subsection{False Certainty of Positivism}

The educational research is faced with the old-fashioned frameworks that reject change according to the needs of the current education systems. Barnett (2000) identifies a situation whereby researchers have been inclining towards withdrawing from addressing the uncertainties and complexities of modern education towards protective spaces within which they do not grow but remain entrenched in traditional guided research practices. Mostly the researchers have been reduced to:

- Being reactionary rather than being revolutionary.

- Being old-school and conservative rather than stretching their boundaries to reconstruct research procedures.

- Being proponents of a dominant positivist paradigm rather than embracing uncertainty and reframing their fields of inquiry.

Barnett (2000) and Rorty, Putnam, Conant and Helfrich (2004) argue for the need to de-privilege the dominant positivist inquiry by realizing that other modes of inquiry are of 
equal importance and that they too can also help us to cope with complexities and uncertainties of the world and offer useful tentative responses, possible working ideas and a suggestive course of action and intervention. This view is in contrary to the idea that positivism and scientific inquiries are the only ones that can produce actual reality. It is also contrast to the tendency of championing a single description of educational challenges and the convergence on a single solution to given diverse educational problems.

Murphy (1990) and Geertz (2000) refuse to consider traditional and scientific inquires as dogmas to reality but the only perspectives that can provide possible, tentative and suggestive descriptions about the existing educational challenges. In this manner the research outcomes become liable refinement, contestation and amendments. This process highlights the need for the modern research practices to open up and be reframed to accommodate multiple actors, varied modes of inquiries, multicultural contexts, and a diverse audience.

As argued earlier in this paper, the problem of false certainty stems from still prevailing positivist orientations in research practice, the characteristics of which have diverged away the central roles of research to have an impact on the public. A reflection of the existing crises in education research suggests a shift to a more revolutionary research perspective (Hope \& Waterman, 2003; Mukusha, 2011). This paper relates such a revolutionary world view to the pragmatic approach, a perspective which does not offer specific principles and theories to follow in conducting research but offers a working point of view and a specific way to understand and address problems.

For the sake of clarity about pragmatism the sections that follow discuss the concept of pragmatism, its tenets, forms, and its likely usefulness in educational research practices.

\section{Theorizing the Concept of Pragmatism}

The term pragmatism is derived from the Greek word pragma (meaning deed, work or act), which is a derivative of the word prassō, meaning to pass over, to practice, and/or to achieve (Rosenthal \& Thayer, 2011; Singh, 2007). The etymological meaning identifies pragmatism as a practical (action-oriented) approach to finding solutions for existing problems and issues. Pragmatism signifies practicality, compromise, prudence and a clear goal orientation in dealing with problems. Throughout this paper, pragmatism is identified as an American philosophical movement founded by C. S. Peirce, John Dewey, and William James (Peirce, 1992).

The great fathers of pragmatism (James and Dewey) considered pragmatism as a way of transcending the irresolvable, philosophical and metaphysical dilemmas. In Rorty's view $(1985$, p. 5) pragmatism should be considered as a "forum in which people can talk how to fulfil their needs, which beliefs work to get them what they want, without running into Platonic or Cartesian impasses" (cited by Wicks and Freeman, 1998).Pragmatism is characterized by its ability to accept all well-constructed paradigms of scientific inquiry as valid when they are appropriate, that is, where the nature of studied reality is such that the paradigm leads to useful results. 
Pragmatism has been considered to be a useful lens that can help in understanding debates and discourses in complex situations (Dewey, 1956; Trohler \& Oelkers, 2005). According to Arif, Smiley, and Kulonda (2005), pragmatism is also related to instrumentalism as propounded by John Dewey and it is related to real-world applications of knowledge and skills attained by learners as a product of schooling (Dewey, 1897, 1973). Pragmatism is also based on progressivism where value is placed on knowledge that is useful for survival (Reed \& Johnson, 2000).

In practice, pragmatism could be considered as a confrontation with reality through action as a principal source of doubt, which in turn feeds scientific curiosity and becomes the driving force to inquire in order to settle that doubt. Thus, action and the interrogations stemming from it are what drive the agenda of the discussion (Peirce, 1998). The central doctrine of pragmatism is therefore grounded upon judging the value of ideas based on their practical bearing and the functions they have in guiding actions (Pratt, 2002; Rescher, 2000; Robert, 2000). Classical pragmatists, such as Peirce, James and Dewey, opposed the theory of truth and knowledge as representation. In their view knowledge and the acquisition of knowledge should be focused within the concept of action, work and consequences to people's lives (Rorty, 2004; Biesta \& Burbules, 2003). These pragmatists were against falling into the solipsism, subjectivity and relativistic concepts of truth by the notion of dogmatic definition and understanding about the concepts.

Pragmatism is also viewed asa philosophy that invites deep commitment to practice. Pragmatists see their action as driven by dialectics, a process of arriving at truth through confrontation of different points of view. Hence, the most common interpretation of the term pragmatism is applying what works best, making it a philosophy or theory of 'workability' (Delputte, 2013; Enoh, 1995). To the pragmatists what is true is what works best in enabling one to overcome an immediate problem (Okoh, 2003). They also view knowledge in terms of its ability to work and provide satisfactory impacts. With the world constantly changing, what works today may not necessarily work in the future; therefore, because of the constant changes in global knowledge, there is no absolute truth in pragmatism.

Pragmatists can be categorized into three major categories:

- The classical pragmatist (1850-1950) including people such as Charles Sanders Pierce, William James, John Dewey and F.C.H Schiller. This group of pragmatists put forward the foundations under which truth, knowledge, wisdom, ideas and thoughts can be defined (Stumpf \& Fieser, 2008).

- Theanalytical neo-classical pragmatists including, among others, individuals such as Joseph Margolis, Hilary Putman, Richard Rorty, Willard Van Orman Quine, Nicholas Rescher, Isaack Levi and Susan Haack. This group of pragmatists describe pragmatism as theory of life experiences and objective truth and somehow making a difference in people's daily lives. 
- The other pragmatists include those such as Oliver Wendell Holmes Jr, Steven Breyer, and Richard Polsner. These are individuals who integrated pragmatic perspectives in law studies.

The current drive by contemporary pragmatists is focused towards solving the challenges in education. Their belief is built on the consideration that rather than striving to attain absolutes or certainty in educational practices, efforts should be made to come up with some ways that work and make sense of the present educational experiences (Gideon, 2003; Pratt, 2002; Robert, 2000; Rorty, 2004). In so doing, these contemporary pragmatists also provide the foundation for developing ideas that is likely to work best in specific educational systems.

The philosophical roots of modern-day pragmatism lie in the objections of some features of logical positivism and the celebration of a moderate level of specificity and application of concrete situations (Franke\& Jager, 2013; Pierce, 1935). To be useful, a pragmatic approach emphasizes key issues that are important to address for successful implementation or evaluation of specified educational interventions (Hamati-Ataya, 2012).At all times pragmatism has been considered as a process rather than a result, and it is an approach that attempts to validate all participatory variables in a solution specific to educational problems. This means that in pragmatism the task, then, is to find solutions that make the most sense in the simplest way possible. A pragmatic measure of a useful idea would be its relevance to stakeholders and its likelihood to be applicable in most real-world settings.

\subsection{Forms of Pragmatism}

The literature identifies pragmatism as a multi-constructed philosophy (Mcdermid, 2006).In particular, the pragmatic perspective happens to occur in different forms as summarized in Table 1.

Table 1. Forms of Pragmatism in research practice

\begin{tabular}{l|l|l}
\hline Dimension & Focus & Beliefs \\
\hline Humanistic & $\begin{array}{l}\text { Satisfaction of the needs, } \\
\text { requirements, aspirations and } \\
\text { objectives of human beings and caters } \\
\text { to the welfare of mankind. }\end{array}$ & $\begin{array}{l}\text {-Problems as the motives of } \\
\text { truth } \\
\text {-Social and democratic values } \\
\text {-Importance of manpower }\end{array}$ \\
\hline Experimentalism & $\begin{array}{l}\text { Verifiable knowledge through } \\
\text { experiments }\end{array}$ & -Activity and consequence \\
& $\begin{array}{l}\text { Enables the individual to adjust with } \\
\text { the environment and to change it to suit } \\
\text { his needs and requirements. }\end{array}$ & -Changing nature of truth \\
\hline
\end{tabular}




\begin{tabular}{l|l|l}
\hline Consequentialism & $\begin{array}{l}\text { Some utility functions for mankind in a } \\
\text { certain set of times i.e., such } \\
\text { knowledge has positive consequences } \\
\text { or results. }\end{array}$ & -Truth is formed by its results \\
\hline Progressivism & $\begin{array}{l}\text {-New values for an unknown future, a } \\
\text { better, happier and richer life. }\end{array}$ & $\begin{array}{l}\text {-Opposes fixed social customs } \\
\text { and traditions, absolute values } \\
\text { and ideas }\end{array}$ \\
\hline Optimism & $\begin{array}{l}\text { Dynamic, flexible and adaptable } \\
\text { knowledge that can help in creating } \\
\text { new values for an unknown future. }\end{array}$ & $\begin{array}{l}\text {-Faith in the present and } \\
\text { future } \\
\text {-Practical coping with the } \\
\text { problems in the context of the } \\
\text { day-to-day realities }\end{array}$ \\
\hline Pluralism & $\begin{array}{l}\text { Diverse view about knowledge and the } \\
\text { working ideas. }\end{array}$ & $\begin{array}{l}\text {-Pluralism, flexibility and an } \\
\text { opposition to the old doctrines } \\
\text { of idealism and naturalism }\end{array}$
\end{tabular}

\section{Basic Tenets of Pragmatism}

Unlike liberal foundationalism, critical philosophers and/or contemporary political philosophers, pragmatists are not conservative philosophers, but rather they support liberal principles of meliorism, which emphasise the necessity of reforming existing practices and discarding processes that have failed to achieve their intended purposes (Roskelly \& Kate, 1998). In pragmatism there is always room for critical re-examination of best practices (Dewey, 1903). The function of pragmatism is not to critique, but to help in a workable course of action within a context where those involved (SE stakeholders in this particular case) are not neutral to the process but directly engaged in the discussion (Delputte, 2013). Unlike other philosophical views, pragmatism does not involve a collection of arguments or points of view; rather, each argument is assessed for its contribution to on-going practices (Anderson, 1990). The pragmatic perspective, therefore, is more suitable for critical analysis of issues within a society than many other worldviews, including those laid out by critical studies.

In contrast to logical positivism, which incorporates only epistemology and logic, pragmatism as applied today includes all five branches of philosophy (metaphysics, epistemology, logic, ethics, and aesthetics) in articulating the whole of a particular phenomenon (Rescher, 2000). It is also distinct from realism in a sense that it is built under the idea that we live in order to learn. Pragmatism, by contrast, insists on "learning in order to live" (Ardalan, 2008, p. 22).

In relation to other more positivist philosophical orientations where arguments are accustomed and absolutist in nature, pragmatism contains a realistic reflection whereby the 
validity, relevance and usefulness of the arguments are the issues of central concern. In general, pragmatism assumes a non-aligned position where multiple views about knowledge are favoured. For this reason, pragmatism is preferred as an approach for creating harmony among opposing philosophical standpoints (Rosamond, 2007).

\section{Pragmatism and Educational Research}

Pragmatism is taken to be an outgrowth of British empiricism, which is based on both transformational and instrumentalist philosophy in education (James, 2000; Sleeper, 2001). Pragmatism, as used in this paper, is identified by its ability to link new experiences in school to those of the wider society. Roskelly and Kate (1998) conventionally posit that the pragmatist looks for the most efficient means to an end, without stopping to question the authenticity of the practices at hand, because focusing on those details would reduce the efficiency and practicality of the practice. Pragmatism, as viewed today, is a holistic philosophy that works to manage the world and human experience in ways that produce the best connections to daily actions, requiring real examples and real-life experiences (Creswell, 2003; Fontrodona, 2002; Rescher, 2000; Rorty, 2004). James (1907) argued that pragmatism focuses on making "a positive connection with the actual world of finite human lives" (p. 20). It also looks towards "concreteness and adequacy, towards facts, towards action and towards power (James, 1907 pp.51)”.

Pragmatists believe that educational research must be conceived as a continuing reconstruction of educational experiences. Dewey (1903) relates such experiential reconstruction to being a process through which traditional practices in education are revised in light of what has been learned about their consequences. He also considers pragmatism to be useful in eliminating the gap that exists between what is learnt in schools and public needs and preferences. Dewey, and all other pragmatists, asserts that genuine knowledge emanates from the problems or difficulties that exist in society. This implies the need for linking theory to practice, and connecting educational experiences to the students' interests and needs. Dewey (1897) argues pragmatic educational research creates the possibility of education being "a process of living and not a preparation for future living" (pp. 78-80). This is because in pragmatism the goal of learning changes from dwelling on non-working educational ideas to creating constantly new competences that fit the contemporary situation so that instead of reproducing current habits, better habits are formed and thus the future adult society is improved (Dewey, 1897; Parker, 2003).

Singh (2007) claims that pragmatism does not believe in fixed aims of educational research, because human needs always change with changing times, places and circumstances. It is noted by this author that no specific aims, frameworks and methods of educational research can hold true and be applicable at all times, or in all places or situations. It is therefore necessary to have aims that enable the researcher to continuously grow and create new values, which provide him/her with dynamic direction and guidance towards intrinsic interest, strong attitude and capacities in the their areas of specialisation. 


\section{Benefits of Using a Pragmatic Approach in Educational Research}

Beyond the present philosophical criticisms of pragmatism as a methodological approach in research, James (2000) argued that the pragmatic approach by its very nature allows for the dynamic interplay between theory and practice, and in that case it makes the knowledge always under construction. As applied in this paper, pragmatism is viewed as a line of inquiry that helps in shifting conceptions about knowledge from fixed, faulty and rigid standpoints (in this case fixed research orientations and practices) to more diverse and inclusive ways in the practice of educational research. It is also considered helpful in finding out how philosophical conceptions, assumed as beliefs, can influence research practices, thus providing an opportunity to investigate the bearings of these conceptions in practice (Taatila $\&$ Raij, 2012). With its ability to stretch the dogmas and universally unchanging practices in education, pragmatism is likely to be helpful in modifying and updating non-working research practices by setting each one to work (James, 1907). Most pragmatists, such as Ackoff and Emery (1972) and Churchman (1979), describe positivism and/or constructivism as being capable of accounting for only a fraction of social reality on their own. The fraction of reality produced by these lenses is necessary but insufficient. In the context of this paper, pragmatism is relevant in a number ways, as described in the sub-sections that follow.

\subsection{Pluralistic View in Addressing Research Issues}

Pragmatism embraces the notion of plural and dynamic realities (multiple truths) or in other words, that there is no knowledge that is certain and/or universal. Pragmatism not only rejects the narrow confines and structures of absolutism but also offers an approach grounded in the emerging conversation that supports a diversity of viewpoints about the phenomena (Creswell, 2003; Rorty, 2004; Rosamond, 2007). Unlike other worldviews, pragmatism is not informed by formal theory, but by accumulated practices, practitioner and administrator knowledge, the findings from previous research and the views expressed by the public (Biesta $\&$ Burbules, 2003). It is argued in this paper that pragmatism offers a more diverse and interpretive approach that would help to solve problems facing the educational research and practice as it refutes the Aristotelian methods (belief in given reality) and one-dimensional constructs.

\subsection{Emphasis on What Works Best in Solving Educational Issues}

Pragmatism emphasises what works best, that is, finding a measure of goodness that works rather than what may be 'inherently' true as celebrated by positivists (Goodman, 2005; Rosenthal\&Thayer, 2011). Pragmatism is well known for its emphasis on utility of all educational practices in that only those subjects, activities and experiences that are useful to the present needs of the learner and that meet the future expectations of adult life are included in the curriculum (Petrou, 2007). Runes (1983) looks at pragmatism as a philosophical movement that stresses practical consequences and values as standards by which concepts are to be analysed and their validity determined. In other words, pragmatism is the philosophical notion that ideas or principles are true so far as they work. In Runes' view, pragmatism heavily relies on empirical or experimental methods and rejects patriotism (innate or intuitive processes and mechanisms of knowing) as a source of human knowledge. 
In this paper pragmatism is also viewed as the world view that is likely to provide an avenue to test the utility of educational research outcomes; here utility could be related to the fulfilment of the societal needs. The assumption that this paper holds is that utility of the education research outcomes should be the first criterion for judging whether a certain methodological perspective is effective or not.

\subsection{Emphasis on the Changing Roles of Educational Research}

Pragmatists do not believe in any pre-conceived, final, fixed and immutable strategies to doing research as advocated by positivistic theorising (Johnson \& Onwuegbuzie, 2004; Morgan, 2007; Patton, 2002). The belief celebrated by pragmatists is that the aims of educational research of producing on-going experiences should lie wholly within improving the educational practice. With a changing world full of uncertainty and a shifting future, educational experiences are prone to change (Creswell, 2009). In such a dynamic environment there is a need to reshape the existing aims of educational research practices to meet new research methodological needs and this is possible through pragmatism. In a situation like this whereby the positivist theorising and scientific-based research have dominated the research practices, there is a need for researchers to engage with those issues that are not easily measurable.

\subsection{Assertion of Connecting Theory to Practice}

Pragmatists believe that knowledge results through interactions (action or doing) in which the individuals interacting experience the consequences of their actions and can use this knowledge to solve subsequent problems (Levin \& Greenwood, 2011). Therefore, for one to acquire the necessary knowledge to solve problems, interaction is a necessary component (Dewey, 1944). In Enoh's (1995) book, Dewey states that "there is no such thing as genuine knowledge and fruitful understanding except as the offspring of doing" (p.109). By implication, this means that learning by doing is important for developing a strong knowledgebase among learners. In contradiction with Dewey's view, however, the research practices reveal a disconnection between the theory building process and consideration of its usefulness in practice, the process which makes most research outcomes not practically useful in solving the societal educational problems.

\subsection{Contention of Changing Research Methodological Practices}

As a solution to the constantly changing world and knowledge, the research practices need to be updated in order to best address evolving issues. In this case, pragmatists recommend the type of approach that is dynamic in addressing the issues that face society (Dewey, 1944; Nzeneri, 2010). A fault currently identified in the current educational research practices is that positivistic and constructivist research practices are regarded as separate entities with no direct connection with other forms of research inquiries. This situation presents the need to redefine the ideological commitments of research so that both forms may either singly or combined provide meaningful, relevant and functional outcomes to society. Pragmatism qualifies as a relevant approach towards bridging the gaps between the two contrasting research philosophies, especially when the educational research needs to function as a 
constant reconstruction or reorganisation of experiences to meet the challenges of later problems (Dewey, 1944).

\subsection{Assertion of Educational Research Outcomes towards Utility Function}

Pragmatists believe that effective education research is not only one that is able to link new experiences in school to those required in society, but is one that is derived from human needs and desires (Dewey, 1944). Pragmatists insist on educational practices being related to society's interests and experiences, and consider this a central aim for conducting research. Pragmatism favours diverse approaches in order to take care of differences between research interests, and also to centre the needs of society as owners of the research outcomes. Using a single or just a few approaches to research is to ignore important diversity and the complexity of the educational problems. This is one reason why this paper places pragmatism as a relevant theoretical lens for examining the connection between educational research outcomes and overall community needs. Another reason is that pragmatism may also help in providing solutions to the present predicament crisis in educational research, especially in closing the gap between research outcomes and the community expectations of educational research.

\subsection{Promotion of Democratic-Based Research}

Pragmatists are attracted by the idea of democracy because in a democratic community there is give and take; free interaction exists between individuals and social groups, and there is an exercise of human freedom, character, intelligence and other potentialities (Enoh, 1995). This paper argues that in a situation where research philosophies oblige the researcher to accept and adhere to whatever comes from them, it is necessary for educational research practices to be made democratic, where researchers are left free to choose a methodological path that suits a specific problem in the discovery and extension of knowledge. The role of a specific research methodology should therefore be to lay foundations that would enable researchers to embrace the spirit of wanting to explore more, rather than being forced to only behave and conduct research activities as stipulated in a specified worldview.

\subsection{Supporting the Production of Relevant and Functional Knowledge}

Pragmatism aims at creating useful knowledge by addressing the pressing issues, contemporary problems and transferring acquired knowledge into action. In pragmatism knowledge is considered to be true and valuable only to the extent of its contribution to a specific context. The pragmatic approach supports the connection between knowledge, experience and practice. To pragmatists, scientific knowledge is useful when it helps people to better cope with the world or to create better organizations. The notion of usefulness applies across two dimensions: epistemological (is this information credible, well-founded, and reliable?) and normative (does this help advance our projects?) (Wicks \&Freeman, 1998).

Generally, it can be argued that pragmatic positions echo more radical postmodern stances that reject the rhetoric methodological practices which do not serve very well for any practical purposes and lead to questionable usefulness of research outcomes. It is argued in this paper that there is a need for 'middle ground' between clearly problematic modernist 
epistemological stances and radical postmodern positions. It is about taking a shift from positivist positions while not falling into radical constructivism that would not provide any convenient way to talk about 'real' phenomena.

\section{Criticisms of Pragmatism}

Pragmatism has been criticized by other philosophical schools of thought known as realism, conservative religious thinkers, and by critics on the left. There are a number of criticisms of pragmatism as a line of thinking. These include a view that it reduces ideas to a doctrine of pure expediency in attaining unquestionable ends (Woodbridge, 1904) and a failure to distinguish the notion about the consequences of the truth of a proposition and belief in a proposition (Lovejoy,1908). Also, contemporary pragmatism as represented by Richard Rorty has been criticised by Haack $(1997,2006)$ and Dennett (1998) as being epistemologically relativistic and as having a short-sighted practicality similar to an adhoc approach (i.e.,an approach set up solely in response to a specific situation or problem, which works without considering wider or long-term issues).

While accepting the existence of these critics, there are genuine attributes that make the pragmatic perspective useful in educational research and especially in this era of methodological tug of war. For example, pragmatism usually holds a neutral position in various ideological debates while establishing its ability to engage in value-critical analysis about those arguments when necessary. In practice, pragmatism takes a middle ground between philosophical liberalism (which supports critique and reforms) and conservatism which values preserving the existing practices and the established ways of doing things (Taatila \& Raij, 2012). Anderson (1987) differentiates pragmatism from liberal scepticism by describing pragmatism as "a gentler Aristotelian form of criticism in which established practices are accepted as having inherent value but are subjected to reconsideration in the light of critical analysis and reflection" (p. 354).

To regard pragmatism as ad hoc is to neglect the fact that pragmatism in its truest sense is a philosophy in which there is no need to apologise for reconstructing principles and methods around concrete social problem solving. Given such a role, pragmatism remains an approach that is contextual, relevant and progressive rather than strictly ad hoc. Also, what makes pragmatic approaches strong is how useful they are in guiding action in real-world settings. Thus, pragmatic approaches are generally more concrete and specific than abstract theories.

Randolph Bourne, the brilliant cultural critic and Columbia graduate who had studied with Dewey, was the first of a whole series of radical critics of pragmatism who argued that pragmatists, in their insistence that what is true is what works, had essentially paralyzed the imagination; they had disabled the creativity of researchers as human beings in the face of an unjust order. Sometimes, Bourne and other leftist critics argued what is true is what doesn't work, what stands at odds with the existing state of affairs, and one must stay loyal to that truth in the face of a hostile environment.

Although pragmatism in its truest sense may be viewed as a cultural global package that does not match some contexts such as the African traditional educational culture and that 
pragmatism is a vague philosophy that should not be relied upon, it should be noted that African education, especially a traditional one, is both essentialist and pragmatic in nature (Fafunwa \& Aisiku, 1982; Ramose, 1999). This contention solves a limitation common to non-pragmatists that usually there is a problem related to the effective and efficient application of pragmatism in non-American contexts. Despite the pragmatic limitations alluded to, pragmatism can still be regarded as a useful lens for understanding and solving the current research crises in education.

In the search for practical applications of research outcomes in education, pragmatism celebrates the synthesis of varied and sometimes conflicting ideas into useful new theories and practices. For example, in solving the complex educational problems the pragmatic approach can help in combining various stakeholders' voices together with the traditional methodologies and with more critical recommendations in addressing some complex and multifaceted issues in education. This goes beyond advancing the theoretical stances of other theoretical stances to addressing stakeholders' concerns in relation to the quality of research and its outputs.

\section{Implications of Using Pragmatic Approaches in Educational Research}

In addressing the research methodological predicaments, pragmatism happens to be the most suited line of inquiry. The application of a pragmatic approach in educational research as articulated in this paper seems to have several notable implications:

- It is likely that all research propositions will not be presented as axioms of a formal theory, but rather as tentative, suggestive, and working points of view which are susceptible to critique.

- It becomes possible to witness the research outcomes being drawn from a wide range of theories and models that incorporate multiple insights.

- It is possible to see the research processes and outcomes that are more direct, inclusive, relevant, functional, and balanced.

- It is likely that research activities will stop producing dogmas and complete theories but rather working points of views.

- It is likely that pragmatism will be adopted as a non-ideological, compromising, and reformist perspective that is based on the experience of doubt and uncertainty.

- It is possible that researchers will start producing tentative and fuzzy research outcomes and suggestions rather than entrenching on given reality and dogmatic modes of inquiry-led practices.

- It is likely to transform researchers from finding the ultimate correctness (objective truth) which is actually absent towards keeping the conversation going. 
Generally, adapting a pragmatic approach to educational research is likely to help in overcoming various crises that have been identified in the earlier sections. Pragmatism in this case serves not as an alternative model of research but as a more working point of a view or a perspective which is admittedly modest, bringing solutions to most research methodological challenges. In practice, pragmatism would lead to thoughtful reflection about how best research can be done and provide direction to the educational practice. All it does is providing possible lines of action.

A pragmatic approach is equipped to resolve the apparent inconsistency between positivists, constructivists, and scientific researchers. With pragmatism it is possible to create, uphold, and reinforce different world views to be integrated into a single line of evidence. The basic foundation of the modern pragmatism is its reliance on solving disputes of interest through dialogue, negotiation, argumentation, and consensus (Habermas, 1990).

\section{Conclusion}

In conclusion, this paper has attempted to critically discuss pragmatic stances towards solving the problematic epistemological crisis in educational research. Having noticed the crisis in educational research practices, perhaps one way to solve these problems is by adopting the pragmatic approaches which seem to have the ability to resolve global conflicts when all other resolution processes - including and especially dominant ones - have been exhausted and the parties involved just want the fighting to end at all costs. The discussion has shown that pragmatism is experiential, instrumental, empiricist, and based on growth principles. But also with a brief analysis of its historical background, conceptual analysis, its link to education, curriculum, knowledge, teachers' roles, pedagogy, the learner, and school experiences, it is safe to give an informed conclusion that there is a need for a pragmatic approach in educational research to minimise the methodological challenges in the current research practices.

The implementation of pragmatism as a methodological philosophy in educational research is likely to improve the outcomes of educational research by changing them from being the actual descriptions of reality to being possible connections between actions and consequences. This means that the educational research becomes transformed from being a recipe for truth to being the possible line of action that provides a working point of view and an alternative perspective in the search for better means and methods of educational practice. This initiative characterizes the shift towards a framework that works at the level of the researcher looking for useful theories and the useful understandings of new problems in order to achieve satisfactory practice. This way the approach provides the researcher with an alternative to the Cartesian anxieties existing in educational research. In particular, it opens the way to both theorizing practice and reflexivity on the practice of knowledge generation.

\section{Acknowledgement}

I cannot express enough thanks to my $\mathrm{PhD}$ supervisors for their continued support and encouragement: Dr.Barrie Gordon; Prof. Luanna Meyer; and Dr.Azra Moeed. I offer my 
sincere appreciation for the learning and mentoring opportunities provided to me by my supervisors.

\section{References}

Ackoff, R.L., \& Emery, F.E. (1972). On purposeful systems. Adline Adherton, Chicago, IL.

Anderson, C. (1990). Pragmatic liberalism. Chicago, IL: University of Chicago Press.

Anderson, C. (1987). Political philosophy, practical reasons and policy analysis. In F. Fischer and J. Forester (Eds.), Confronting values in policy analysis: The politics of criteria(p. 22-44). Newbury Park, CA: Sage.

Ardalan, K. (2008). The philosophical foundation of the Lecture-Versus-Case controversy. Its implications for course goals, objectives and contents, International Journal of Social Economics, 35(1 \&2), 15-34. http://dx.doi.org/10.1108/03068290810843819

Arif, M., Smiley, F. M., \& Kulonda, D. J. (2005). Business and education as push-pull processes: An alliance of philosophy and practice. Education, 125(4), 602.

Badley, G. (2003). The crisis in educational research: a pragmatic approach. European Educational Research Journal, 2(2), 295-308. http://dx.doi.org/10.2304/eerj.2003.2.2.7

Barnett, R. (2000). University knowledge in an age of super complexity, Higher Education, 40, 409-422. http://dx.doi.org/10.1023/A:1004159513741

Biesta, G.J.J., \& Burbules, N. (2003).Pragmatism and educational research. Lanham, MD: Rowman and Littlefield.

Brew, A. (2001). Conceptions of research: A phenomenographic study, Studies in Higher Education, 26, 271-285. http://dx.doi.org/10.1080/03075070120076255

Churchman, C.W. (1979). The systems approach and its enemies. Basic Books, New York, NY.

Creswell, J. W. (2003). Research design: Qualitative, quantitative and mixed methods approaches. Thousand Oaks, CA: Sage.

Creswell, J. W. (2009). Research design: Qualitative, quantitative, and mixed methods approaches (3rd ed.). Thousand Oaks, CA: Sage.

Degen, J. (2013). Alternatives in pragmatic reasoning. Unpublished doctoral dissertation, University of Rochester.

Delputte, S. (2013). The EU as an emerging coordinator in development cooperation: Perspectives from sub-Saharan Africa1. AFRIKA FOCUS, 26(1), 99-107.

Dennett, D. (1998). Brainchildren: Essays on designing minds. Cambridge, MA, MIT Press.

Dewey, J. (1897). My pedagogic creed. School Journal, 54, 77-80 


\section{Macrothink}

Journal of Studies in Education

ISSN 2162-6952

2015, Vol. 5, No. 1

Dewey, J. (1903). Logical conditions of a scientific treatment of morality. Chicago, IL: University of Chicago Press.

Dewey, J. (1944). Democracy and education. New York: The free press.

Dewey, J. (1956). The child and the curriculum, and the school and society. Chicago, IL: University of Chicago Press.

Dewey, J. (1973). Education as a social function. In S. D. Sieber \& D. D. Wilder (Eds.), the School in society (pp. 28-33). New York, NY: The Free Press.

Enoh, A. O. (1995). Introduction to philosophy of education. Jos: Midland Press (Nigeria) Ltd.

Fafunwa, A.B., \& Aisiku, J.C. (1982). Education in Africa: A comparative survey, London: George Allen \& Unwin.

Fontrodona, J. (2002). Pragmatism and management inquiry. New York: Quorum Books.

Franke, M.C., \& Jager, G. (2013). Pragmatic back-and-forth reasoning. Manuscript, Amsterdam:Tubingen.

Geertz, C. (2000). Available light: Anthropological reflections on philosophical topics. Princeton: Princeton University Press.

Gideon, C. (2003). Rorty and re-description. London: Weidenfeld \& Nicolson.

Glasgow, R. E., \& Riley, W. T. (2013). Pragmatic measures: What they are and why we need them. American Journal of Preventive Medicine, 45(2), 237-243. http://dx.doi.org/10.1016/j.amepre.2013.03.010

Goodman, R. (Ed) (2005). Pragmatism: Critical concepts in philosophy. London: Routledge

Haack, S. (1997). Vulgar Rortyism. New Criterion, 16(3), 67-70

Haack, S. (ed) (2006). Pragmatism, Old and New. Amherst NY: Prometheus

Habermas, J. (1990). Moral consciousness and communicative action, trans. by C. L. Lemhardt and S. W. Nicholsen. Cambridge, MA: MIT Press.

Hammersley, M. (2002). Educational research, policymaking and practice (London, Paul Chapman Sage).

Hamati-Ataya, I. (2012). Beyond (post) positivism: The missed promises of systemic pragmatism. International Studies Quarterly, 56(2), 291-305. http://dx.doi.org/10.1111/j.1468-2478.2011.00710.x

Holt, J. (2009).A pragmatic guide to business process modelling, second edition. BCS, the Chartered Institute for IT, Swindon. 
Hope, K. W., \& Waterman, H. A. (2003). Praiseworthy pragmatism? Validity and action

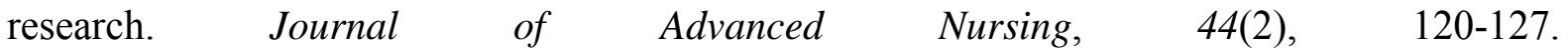
http://dx.doi.org/10.1046/j.1365-2648.2003.02777.x

James, W. (2000). What Pragmatism Means. In J. J. Stuhr (ed.), Pragmatism and classical American philosophy: Essential readings and interpretive essays. New York: Oxford University Press.

James, W. (1979). The moral philosopher and the moral life: The will to believe and other essays in popular philosophy. Cambridge: Harvard University Press.

James, W. (1907). Pragmatism, a new name for some old ways of thinking: Popular lectures on philosophy. New York, Longmans, Green, and Co. http://dx.doi.org/10.1037/10851-000

Johnson, R., \& Onwuegbuzie, A. (2004). Mixed methods research: a research paradigm whose time has come. Educational Researcher, 33(7) 14-26. http://dx.doi.org/10.3102/0013189X033007014

Kompridis,N. (2006). Two kinds of fallibilism: Critique and disclosure. Cambridge: MIT Press.

Levin, M., \& Greenwood, D. (2011). Revitalizing university by reinventing the social sciences. In N. K. Denzin \& Y. S. Lincolin (Eds.). The sage handbook ofqualitative research, 4(27-42). London, England: Sage.

Lovejoy, A. O. (1908). The thirteen pragmatisms. The Journal of Philosophy, I, 5-12.

Maxcy, S. J. (2003). Pragmatic threads in mixed methods research for multiple modes: The search for multiple modes of inquiry and the end of the philosophy of formalism, in A. Tashakkori, and C. Teddlie (Eds) Handbook of mixed methods in social and behavioural research, pp. 51-89. Thousand Oaks, CA: Sage.

McDermid, D. (2006). The varieties of pragmatism: Truth, realism, and knowledge from James to Rorty. London and New York: Continuum.

Morgan, D. L. (2007). Paradigms lost and pragmatism regained. Journal of Mixed Methods Research, 1(1), 48-76. http://dx.doi.org/10.1177/2345678906292462

Mukusha, J. (2011). Zimbabwean education in a state of abortion under sanctions: Pragmatism is the best concoction. International Journal of Politics and Good Governance, 2(4), 0976 - 1195

Murphy, J. P. (1990). Pragmatism: From Peirce to Davidson. Boulder, CO: Westview Press.

Nzeneri, I.S. (2010). Adults in battle: Any hope of victory? An Inaugural Lecture Series 71, Presented to University of Port Harcourt.

Okoh, J.D. (2003). Philosophy of education (the basics). Port Harcourt: Pearl Publishers.

Parker, W. C. (2003). Teaching democracy: Unity and diversity in public life. New York, Teachers College Press). 
Patton, M. Q. (2002). Qualitative evaluation and research methods $\left(3^{\text {rd }}\right.$ ed.) Thousand Oaks, CA: Sage

Petrou, M. (2007). Teachers' mathematics content knowledge. Paper presented at the European Research in Mathematics Education, Larnaca,Cyprus. Retrieved from http://ermeweb.free.fr/CERME\%205/WG11/11_Petrou.pdf on 23 march 2013.

Peirce, C.S. (1998). The essential Peirce 2. Peirce Edition Project, Bloomington: Indiana University Press.

Peirce, C. S. (1992). The essential Peirce: Selected philosophical writings, Vol.1. (Indianapolis, IN, Indiana University Press).

Pierce, C. P. (1935). Collected papers of Charles Sanders Peirce, Volumes V and VI: Pragmatism and pragmaticism and scientific metaphysics. Cambridge, MA: Harvard University Press.

Pratt, S. (2002). Native pragmatism: Rethinking the roots of American philosophy. Indiana University Press: Indianapolis, IN.

Pring, R. (2002). The virtues and vices of an educational researcher. In McNamee, M., \& Bridges, D. (Eds.).Theethics of educational research. London: Blackwell.

Rallis, S. F., \& Rossman, G. B. (2003). Mixed methods in evaluation contexts: A pragmatic framework, in A. Tashakkori and C. Teddlie (Eds.).Handbook of mixed methods in social and behavioural research, pp. 491-512. Thousand Oaks, CA: Sage.

Ramose, M.B. (1999). African philosophy through Ubuntu. Harare: Mond Books.

Reed, R, F., \& Johnson, T, W. (2000). Philosophical documents in education. New York: Addison-Wesley.

Rescher, N. (2000). Realistic pragmatism. Albany: SUNY Press. Books.

Rorty, R. (1985). Solidarity or objectivity. In R. Rorty 1991. Philosophical papers, 1, Objectivity, relativism, and truth (pp. 21-34).Cambridge: Cambridge University Press.

Robert, B. (ed). (2000). Rorty and his critics. Oxford: Blackwell Publishing.

Rorty, Richard (1982). Method, Social Science, Social Hope", in Essays (1972-1980) Consequence of pragmatism, Minneapolis: University of Minnesota Press, pp. 191-210

Rorty, R. (1990). The banality of pragmatism and the poetics of justice. Southern California, Law Review, 63, 1815.

Rorty, R. (1991). Philosophical papers volume 1: Objectivity, relativism, and truth. Cambridge: Cambridge University Press.

Rorty, R. (1999a). Philosophy and social hope. New York: Penguin Books.

Rorty, R. (1999b).Achieving our country, Harvard University press, Cambridge, MA 
Rorty, R. (2000a). Reply to Dennett' in Rorty and his critics. Oxford: Blackwell Publishers.

Rorty, R. (2004). Pragmatism. In Routledge Encyclopedia of Philosophy. London: Routledge.

Rorty, R., Putnam, H., Conant, J., \& Helfrich, G. (2004). What is pragmatism? Think, 3(8), 71-88. http://dx.doi.org/10.1017/S1477175600001056

Rosamond, B. (2007). The political sciences of European integration: Disciplinary history and EU studies.In K. E. Jørgensen, M. A. Pollack \& B. Rosamond (Eds.). The SAGE Handbook of European Union politics. London: Sage.

Rosenthal, S. B., \&Thayer, H. S. (2011). Pragmatism. In Encyclopcedia Britannica. Retrieved on $23^{\text {rd }}$ June, 2011 from http://www.britannica.com/EBchecked/topic/473717/pragmatism.

Roskelly, H., \& Kate, R. (1998). Reason to believe: Romanticism, pragmatism, and the teaching of writing. Albany: Suny Press.

Runes, D. D. (1983). Dictionary of philosophy. New York: Philosophical Library.

Schwartz, D., Lellouch J. (1967). Explanatory and pragmatic attitudes in the rapeutical trials. J Chronic Dis, 20, 637-48. http://dx.doi.org/10.1016/0021-9681(67)90041-0

Seltzer-Kelly, D. (2008). Deweyan Darwinism for the Twenty-first Century: Toward and educational method for critical democratic engagement in the era of the institute of education sciences, Educational Theory, 289-304. http://dx.doi.org/10.1111/j.1741-5446.2008.00289.x

Shook, J., \& Margolis, J. (Eds.) (2006). A Companion to pragmatism. Oxford: Blackwell. http://dx.doi.org/10.1002/9780470997079

Singh, Y. K. (2007). Philosophical foundation of education. New Delhi: A P H Publishing.

Sleeper, R.W. (2001). The Necessity of pragmatism: John Dewey's conception of philosophy. Urbana, IL, University of Illinois Press.

Stumpf, S.E., \& Fieser, J. (2008). Socrates to Sartre and beyond: A History of philosophy. New York: McGraw-Hill.

Taatila, V., \& Raij, K. (2012). Philosophical review of pragmatism as a basis for learning by developing pedagogy. Educational Philosophy and Theory, 44(8), 831-844. http://dx.doi.org/10.1111/j.1469-5812.2011.00758.x

Trohler, D., \& Oelkers, J. (Eds.). (2005). Pragmatism and education. Rotterdam:

Wicks, A.C, Freeman, R.E. (1998). Organization studies and the new pragmatism: Positivism, anti-positivism, and the search for ethics. Organization Science, 9, 123-140. http://dx.doi.org/10.1287/orsc.9.2.123

Whitehead, A. N. (1929). The aims of education and other essays. New York: The Free Press.

Woodbridge, F. (1904). Field of logic: Science. New Series, 20(514), 587-600. 


\section{Copyright Disclaimer}

Copyright for this article is retained by the author(s), with first publication rights granted to the journal.This is an open-access article distributed under the terms and conditions of the Creative Commons Attribution license (http://creativecommons.org/licenses/by/3.0/). 